\title{
Reduction of carcass weight loss in swines
}

\author{
Quebra de peso em carcaças suínas
}

Iliani PATINHO ${ }^{1 *}$, Elizandro Pruence NICKELE², Jean Carlos BRUSTOLIN², Magdalena Lajús TRAVI²

\begin{abstract}
The carcass fast freezing is one of the aspects of great prominence to the final quality of pork. In order to reduce weight loss, two experiments were performed, in which the carcasses were monitored during 20 hours to evaluate the main variables involved during two different freezing processes (standard and proposed) as follows: microbiological quality, storage temperature, relative humidity (RH) and air velocity. In experiment $\mathrm{I}$, the carcasses were submitted to a system using heat shock ( 2 hours in static tunnel at $-25^{\circ} \mathrm{C}$ ) and subsequently sent to the equalization chamber. In experiment II, the carcasses were submitted to the heat shock and stored in a chamber with $\mathrm{RH}$ between $80-85 \%$. The chambers used in both experiments showed no change in the variables studied (internal temperature of $5{ }^{\circ} \mathrm{C}$ and air velocity of approximately $0.3 \mathrm{~m} / \mathrm{s}$ ). However, the relative humidity in the three chambers was evaluated and significant differences were found; as a consequence, high levels of weight loss were observed in both chambers In experiment II there was an increase of RH, which reduced the weight loss of the carcasses.
\end{abstract}

Keywords: freezing; pork; quality.

\section{Resumo}

O resfriamento rápido de carcaças é um dos aspectos de grande importância para a qualidade final da carne suína. Com o objetivo de diminuir a quebra de peso, foram realizados dois experimentos em carcaças suínas, que foram acompanhadas durante 20 horas por meio da determinação das principais variáveis envolvidas durante dois diferentes processos de resfriamento (padrão utilizado e outro proposto), sendo elas: temperatura, umidade relativa (UR) e velocidade do ar. No experimento I "padrão", as carcaças foram submetidas à utilização de um sistema de choque térmico (duas horas em túnel estático a $-25^{\circ} \mathrm{C}$ ) e, posteriormente, transportadas à câmara de equalização. Para o experimento II "proposto", as carcaças também foram submetidas ao choque térmico, porém, conduzidas a câmara com UR entre $80 \%$ e $85 \%$. As câmaras analisadas em ambos os experimentos não apresentaram alteração nas variáveis: temperatura interna de $5^{\circ} \mathrm{C}$ e velocidade do ar de aproximadamente $0,3 \mathrm{~m} / \mathrm{s}$ entre as carcaças. Porém, analisou-se a UR das três câmaras e constatou-se uma grande variabilidade entre os dados, em consequência disso, quantificaram-se altos índices de quebra de peso em cada câmara. No experimento II, houve aumento da UR, reduzindo a quebra de peso das carcaças.

Palavras-chave: refrigeração; carne suína; qualidade.

\section{Introduction}

The Brazilian pig raising, as other productive chains of agribusiness grew expressively in recent years. The technique and the model of coordination between suppliers of raw material, rural producers, agro industry, wholesale business, retail and consumers has constantly evolved. It has become a chain of swine production, exploring the activity in an economic and competitive form (OLIVEIRA, 2008).

These constant technological innovations have contributed deeply to the industries of the food sector. However, much information is still unknown concerning the intrinsic and extrinsic quality of the pork in the period after slaughter and before handling. Microbiological changes in the raw pork (in natura) occurs mainly due to intrinsic factors such as water activity, $\mathrm{pH}$, redox potential, and nutritional requirements of the microorganisms and extrinsic factors such as the temperature, relative humidity $(\mathrm{RH})$, oxygen availability in the environment, among others.
According to Zanoelo et al. (2006) the swine carcass is source of various types of raw materials for industry, thus is a focus of great interest in the refrigeration process. In accordance with most of the processes adopted, the swines are received, slaughtered, eviscerated, inspected and subsequently the carcasses are sent to the cooling area. Then, they are stored in refrigeration chambers with controlled temperature until reaching the proper temperature adjusted in the depth intramuscular region of the shank. After cooling, the carcasses are sent to the bonning room for destination and handling of raw materials.

Freezing is a physical method used to conserve meat for longer periods. The preservation by refrigeration and freezing is because reactions that occur in foods delay to occur at low temperatures, due to the temperature regulation and reaction speed. Temperatures around $-30{ }^{\circ} \mathrm{C}$ are needed to obtain food preservation. Freezing the meat, the action of enzymes and

\section{Received 8/1/2010}

Accepted 3/11/2010 (004442)

${ }^{1}$ Graduação em Tecnologia de Alimentos, Faculdade de Tecnologia, SENAI, Rua Quilombo, 240 E, CEP 89809-520, Chapecó, SC, Brasil, e-mail: ily_20_@hotmail.com

2 Núcleo de Alimentos, Faculdade de Tecnologia, SENAI, Rua Frei Bruno, 201, CEP 89808-400, Chapecó, SC, Brasil

*Corresponding author 
the proliferation of microorganisms are inhibited, as water available is frozen. During freezing process, first a frozen crust is formed around the meat and the outer portions dilatate, even though the inside compresses intensely. Temperature, cooling speed and RH must be continuously controlled during freezing. (SIMON, 1983).

According to Drehmer (2005), the reduction of the temperature of carcasses as fast as possible after completed the evisceration is a movement toward reducing the falling speed of muscle $\mathrm{pH}$ and consequently increasing the water retaining capacity (WRC), which is measured through drip loss in free or halothane gene swine carcasses. For this reason, the fast cooling of the carcasses has become a common practice in some agro industries.

Both research and industry have searched to reduce carcasses weight loss, as well as the presence of pathogenic and deteriorative microorganisms. Besides improving the product quality, the purpose of the application of these processes is associated with economic factors.

Given the above, the aim of this study was to reduce the percentage of weight loss in pig carcasses, producing the ideal balance of meat yield and quality muscle without compromising animal welfare and food safety.

\section{Materials and methods}

Two experiments were carried in three equalization chambers (A, B and $\mathrm{C}$ ) in distinct dates (tests) in a swine slaughterhouse in the city of Chapecó-SC, Brazil, from April to June 2009.

First, a survey of the existing standard operation conditions was conducted with the aim of understanding the cooling system of the slaughterhouse as well as the shipment process/ unloading, equalization conditions, operating temperatures and some restrictions during the equalization of carcasses.

\subsection{Experiment I: controlling swine carcass weight loss in the chambers $A, B$ and $C$}

In this experiment, the reduction of weight loss was evaluated. One hundred and five swine carcasses were studied, being analyzed 35 carcasses in each equalization chamber in order to quantify the percentage of weight loss. The variables temperature, $\mathrm{RH}$ and air speed were determined.

The temperature and RH was measured by a digital Thermohygrometer, model TH10, (I-Cute Technology Ltda). The air speed was measured by a portable digital Anemometer, model AD-250, liquid crystal display (LCD) $31 / 2$ digits.

The weight losses of the carcasses were quantified in kilogram. Table 1 indicates the percentage of weight loss in each test, as well as the carcass number, chamber number, date and schedule of accomplishment. The carcasses were stored inside the chambers for 20 hours, as they were weighed again at the beginning of the day after the slaughter, that is, between 5:00 and 6:00 AM.

\subsection{Experiment II: controlling swine carcass weight loss in chamber C}

In this experiment, the reduction of weight loss and the microbiological quality of the swine carcasses were evaluated. This proposed method occurred only in chamber $\mathrm{C}$, where there were 35 swines carcasses. The variables temperature, $\mathrm{RH}$ and air speed were determined as described in 2.1 .

After pre-cooling at $-25^{\circ} \mathrm{C}$ for 2 hours the carcasses were taken to the equalization chamber and remained for 20 hours at $5{ }^{\circ} \mathrm{C}$ with $\mathrm{RH}$ between 80 to $85 \%$. The $\mathrm{RH}$ was changed because the chamber $\mathrm{C}$ is located adjacent the heat shock, where the dry air causes the chamber to present very low $\mathrm{RH}$, causing expressive losses of weight in the carcasses. For uniformity of $\mathrm{RH}$ inside the chamber, water aspersions were done in the inlet pipe of the evaporator. Due to the rapid rotation of the evaporator, water reached around $5 \mathrm{~m}$ from the starting point, forming a mist in the interior of the chamber. The water temperature was cooled to about $5^{\circ} \mathrm{C}$ to avoid ceiling condensation. The carcasses were then submitted at RH between $80-85 \%$ and monitored throughout the equalization.

The microbiological quality of the carcasses was performed by collecting swabs in 6 randomly chosen carcasses during the experiments (before and after spraying water), as described by Normative Instruction 62, August 26, 2003, Ministry of Agriculture, Livestock and Supply (BRASIL, 2006).

Table 2 describes a summary of the experiments and the mean RH in each chamber.

\section{Results and discussion}

Figure 1 shows that due to the low $\mathrm{RH}$ of the chambers, the weight loss was higher, being of $1.25 \%$ at chamber A, $1.09 \%$ at chamber B and $1.62 \%$ at chamber $\mathrm{C}$.

There may be differences when evaluating temperature, $\mathrm{RH}$ and air velocity in the cooling chambers. According to Roça (2009) the cooling rate of a carcass depends on several factors, such as: specific heat of the carcass, weight, amount

Table 1. Spreadsheet used to quantify the weight loss of carcasses, from April to June 2009, Chapecó-SC, Brazil.

\begin{tabular}{|c|c|c|c|c|c|c|c|c|}
\hline \multirow{3}{*}{ Carcass No } & \multicolumn{6}{|c|}{ Spread sheet of Control - weight loss of swine carcasses } & & \\
\hline & & Ent & & & Ex & & \multicolumn{2}{|c|}{ Chamber: } \\
\hline & Hour & Date & Initial weight & Hour & Date & Final Weight & Losses in $\mathrm{kg}$ & Losses in \% \\
\hline
\end{tabular}


Patinho et al.

Table 2. Experiments performed in the slaughterhouse, April-June 2009, Chapecó-SC, Brazil.

\begin{tabular}{|c|c|c|c|c|c|c|c|}
\hline Experiment & $\begin{array}{l}\text { Type of } \\
\text { chamber }\end{array}$ & $\begin{array}{l}\text { Stage } \\
\text { cooling }\end{array}$ & $\begin{array}{c}\text { Temp } \\
{ }^{\circ} \mathrm{C}\end{array}$ & $\begin{array}{c}\text { Time } \\
\text { (hours) }\end{array}$ & $\begin{array}{l}\text { Carcasses } \\
\text { position }\end{array}$ & $\begin{array}{c}\text { Chamber } \\
\text { No. }\end{array}$ & $\begin{array}{l}\text { Relative humidity } \\
(\%)\end{array}$ \\
\hline & & & & & & A & 53 \\
\hline \multirow[t]{2}{*}{ I } & $\begin{array}{l}\text { Static tunnel of } \\
\text { freezing }\end{array}$ & First & -25 & 2 & $\begin{array}{l}\text { Horizontally in } \\
\text { hooks }\end{array}$ & B & 60 \\
\hline & Static of cooling & Second & +5 & 20 & & $\mathrm{C}$ & 46 \\
\hline II & $\begin{array}{l}\text { Static tunnel of } \\
\text { freezing }\end{array}$ & First & -25 & 2 & $\begin{array}{c}\text { Horizontally in } \\
\text { hooks }\end{array}$ & $\mathrm{C}$ & $80-85$ \\
\hline
\end{tabular}

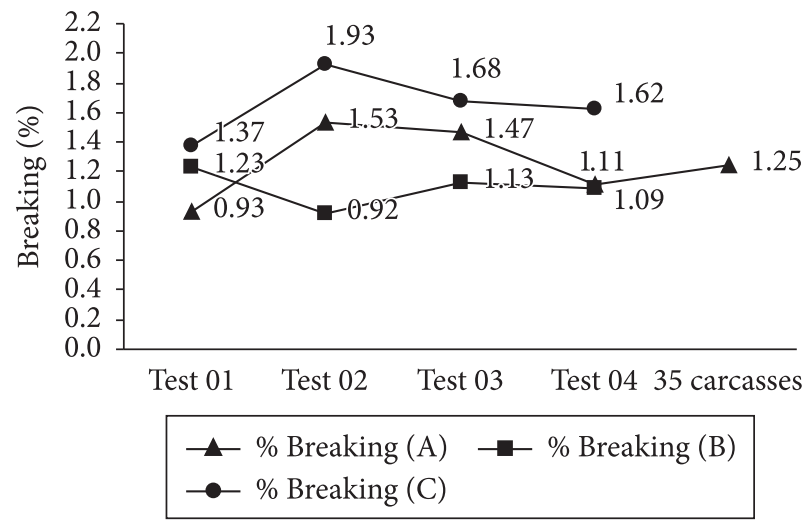

Figure 1. Percent (\%) loss in $\mathrm{kg}$ of swine carcass in the chambers A, B and C by standard freezing from April to June 2009, Chapecó-SC, Brazil.

of external fat and thermal conductivity. Coulter (2008) mentions that the cooling rate may also reveal differences due to the accommodation of the carcasses inside the chamber. Considering all these factors, the results obtained in this study have remained below the results found by Oliveira (2008) in a training developed in a meat processing plant in the city of Sarandi-RS. The author analyzed four cooling chambers and found a percent loss of 2.70 in the first chamber, 3.10 in the second, 2.30 in the third chamber and 2.30 in the last chamber. He stands out that the main factor that may interfere directly the carcass weight loss in the chambers is the storage time, once a proportional relation between increasing the storage time and breaking was observed. However, the relative humidity, that is a factor to be considered, was not measured in the chambers, as well as the air speed.

As each cold storage room has different structures for cooling of carcasses, the percentage obtained in Experiment I may be associated to some problems that interfere with the equalization of carcasses, such as:

- Air Temperature above $-25{ }^{\circ} \mathrm{C}$ in thermal shock and above $5{ }^{\circ} \mathrm{C}$ in the equalization. These factors are related to specific problems in the machine room (refrigerating cycle) and are listed in order of frequency of occurrence:

1. Problem in the temperature controller concerning the calibration and burns (frequency: 6 months);
2. Burning of solenoid valves, that is, those valves that open and close by electric command (frequency: 1 year);

3. Valve of defrosting locked (frequency: 1 year);

4. Fan engines burnt (frequency: 2 years);

5. Imperfection in the automatic thawing or lack of thawing (frequency: 2 years); and

6. Damages in the ammonia bomb (frequency: 3 years).

These occurrences must be observed by the operators in the machine rooms.

- Accumulation of the carcasses: during shipment of the carcasses to the chambers is necessary to observe the interval between carcasses for air passage; it must consider three carcasses for square meter;

- Storage of carcasses with different temperatures inside the same chamber: it must be prevented because it may influence the equalization of the carcasses. The slaughterhouse must be responsible for loading of the chambers, as well as training employees regarding the interval between carcasses; and

- Thermal shock turned off during the passage of the carcass: delays may occur for some reason, happening during the tip schedule (6:30 PM to 9:30 PM), once as established by CELESC (Pilot Plant of Santa Catarina), the industries must diminish the energy consumption due to the increase of energy consumption in the residences during this period. If this happens and the thermal shock is turned off, the equalization of the carcasses will be compromised.

In experiment II, it was observed a decrease of weight loss when RH was controlled (80-85\%) during all the equalization (Figure 2). In this study, the percentage of RH inside the chamber was practically the double, providing a reduction of weight loss of $37 \%$ considering a sampling of 35 carcasses.

Statiscally, the test is unilateral as we want to verify. As can be seen in Table 3, the calculated $\mathrm{t}$ (stat $\mathrm{t}$ ) equal to 7.20. As the unilateral critical $t$ (one-tailed) the value is 2.35 . Once $7.20>2.35$, the nullity hypothesis is rejected and the alternative hypothesis is true. That is, with increasing relative humidity decreases the weight loss, with $95 \%$ confidence.

According to Drehmer (2005), if the relative humidity inside the chamber is too low, the carcass may lose its organoleptic 


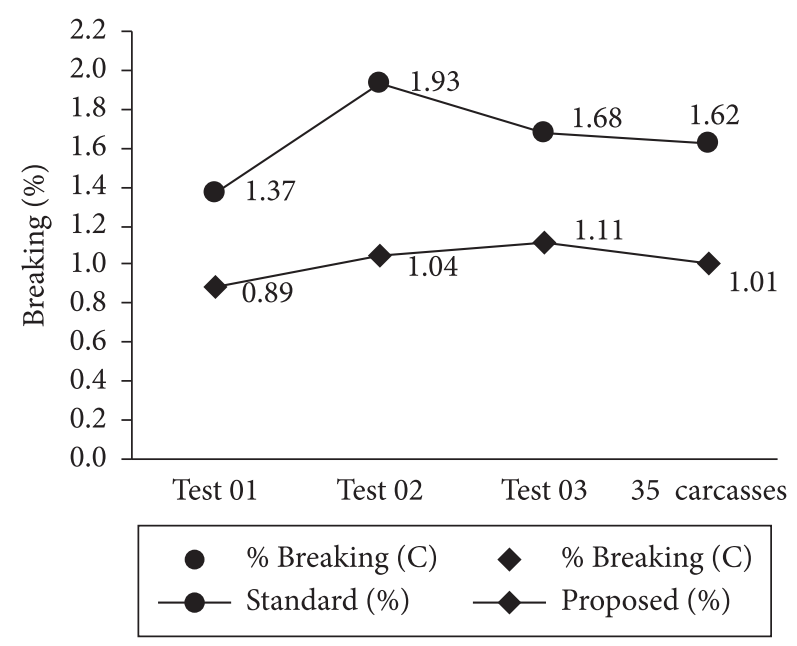

Figure 2. Relationship between the percentage (\%) loss in $\mathrm{kg}$ of swine carcass by standard freezing and the proposed method.

Table 3. Statistical analysis of the data using one-tailed T-test with a 0.05 confidence level.

\begin{tabular}{lcc}
\hline \multicolumn{3}{c}{ T-test: two samples in pair for averages } \\
\hline Average & variable 1 & variable 2 \\
Variance & 1.65 & 1.0125 \\
Comments & 0.05286667 & 0.008425 \\
Pearson correlation & 4 & 4 \\
Hypothesis of the average difference & 0.7107475 & \\
degrees of freedom & 0 & \\
Stat $\mathbf{t}$ & 3 & \\
$\mathrm{P}(\mathrm{T} \leq \mathrm{t})$ one-tailed & $\mathbf{7 . 2 0 7 6 8 5 6 4}$ & \\
$\mathbf{t}$ critical one-tailed & 0.00275263 & \\
$\mathrm{P}(\mathrm{T} \leq \mathrm{t})$ two-tailed & $\mathbf{2 . 3 5 3 3 6 3 0 2}$ & \\
$\mathrm{t}$ critical two-tailed & 0.00550526 & \\
\hline
\end{tabular}

T-test: unilateral.

characteristics. The air speed circulation exerts influence on the heat loss and temperature in the chamber. The more active the air velocity, the greater is the loss of RH. This explains the need to harmonize the atmosphere with relative humidity around $80-90 \%$. These conditions provide greater moisture in the carcasses in such a way, preventing desiccation, which causes the weight losses.

As described by Guahyba (2003), the weight loss or breaking weight by evaporation during the cooling process occurs because the surface temperature is initially much higher than the cold chamber, which can be changed by increasing the relative humidity. The weight loss placed around 1.0 to $1.5 \%$ may reach much higher values (2.5\% or more) by using appropriate cooling.

Maccari (1989) in a research developed in the same slaughterhouse of this study points out that for economic and quality reasons it is suitable that the water or weight loss of the carcass may be within a certain limit. When the meat surface has extreme water loss, it gets an unpleasant aspect and becomes dry and dark. Therefore, relative humidity between 85 and $90 \%$ is recommended. Values above $90 \%$ may promote the formation of slime and development of molds on the meat surface.

During the research, the author monitored the carcasses and found that they remained in the cooling chamber for 24 hours and then were destined to the slashing and expedition. The breaking observed during the cooling of carcasses was of $2.27 \%$ and the final $\mathrm{pH}$ was in the range of 5.5 to 5.8 after 24 hours.

Results obtained by Drehmer (2005) showed that the final percentage of $\mathrm{RH}$ inside the chamber has direct influence under the weight loss during cooling, since the treatments that presented the highest values of final RH had the lowest indexes of breaking at the end of the cooling.

In accordance with Borges (1992), when a static tunnel of freezing is used, the RH must be raised from 85 to $95 \%$, the air speed must reach around $3 \mathrm{~m} / \mathrm{s}$ and the cooling must be performed as soon as possible, so that the weight losses are reduced.

Concerning the microbiological quality, the results showed no changes in the samples of this study.

In general, the faster the cooling of carcasses, the greater its durability and the lesser water loss by dripping and evaporation. In the conventional cooling process, water loss occurs from 2.0 to $2.4 \%$, while in a well lead process of fast cooling the loss is in the order of 1.0 to $1,2 \%$, and in a poorly designed project of fast cooling, there was a drop of weight due to water loss of about 1.8\% (GOMIDE; RAMOS; FONTES, 2006).

Wal, Engel and Beek (2000) evaluated the effects of temperature, weight loss and quality of swine meat. The authors reported about $2.0 \%$ of weight loss after 24 hours of conventional and forced cooling at $-5^{\circ} \mathrm{C}$ (120 minutes). By using the ultra rapid cooling method $\left(30^{\circ} \mathrm{C} / 30\right.$ minutes $)$, losses were reduced to $1.3 \%$.

Joaquim (2002) studied carcass of cattle Nellore breed and found values of relative humidity in the cooling chamber ranging from 55 to $73 \%$, which may have caused a high loss of carcass weight of 1.75 to $1.83 \%$.

According to Powell et al. (1988) apud Lawrie (2005), spraying dilute aqueous emulsion $(<1 \%)$ of cetyl alcohol in sheep and cattle carcasses reduced losses during cooling to $40-80 \%$ and kept the cooling temperature in $22-50 \%$. Carcass treated this way maintained the shiny appearance and presented no microorganisms growth on the surface and no changes in taste of meat.

Greer and Jones (1997) studied lambs and concluded that in the conventional cooling chambers the weight losses of hot carcasses during the first 24 hours may be up to $2.0 \%$

\section{Conclusions}

- The temperature of $-25^{\circ} \mathrm{C}$ in daily precooling for 2 hours and equalization with low relative humidity (46\%) promoted increase in the weight loss of the carcasses, not being recommended the use of low RH values;

- The temperature of $-25^{\circ} \mathrm{C}$ in the daily precooling for 2 hours and equalization with high and controlled relative 
humidity (80-85\%) was efficient in the reduction of weight losses;

- This study showed that relative humidity and weight loss are inversely proportional parameters, as the lower the relative humidity the higher the carcass weight loss in swine or vice versa;

- Experiment I tested the fast cooling and measured the relative humidity inside the three chambers (A, B and C). Chamber $\mathrm{C}$ showed the lowest relative humidity and the higher weight loss;

- Experiment II also tested the fast cooling of 35 carcasses, however, the relative humidity inside the chamber $\mathrm{C}$ was controlled and thus reduced in 37\% the weight loss; and

- Given the results, the optimization of a freezing system applied in swine carcasses has a significant impact on several key aspects, such as meat quality, consumer safety and manufacturing yield. Any reduction in the weight loss will have a significant effect on the profits of agribusiness during the transformation of muscle into meat. When performing the cost analysis in the slaughterhouse by considering the standard experiment and the other proposed in the chamber $\mathrm{C}$ of this study, the monthly net profit was $\mathrm{R} \$ 12,907.64$ (twelve thousand nine hundred and seven reais and sixty-four cents).

\section{References}

BORGES, J. A. Relatório de estágio: Chapecó Companhia Industrial de Alimentos. 1992. 70 f. Relatório de Estágio (Curso Técnico em Alimentos)-Serviço Nacional de Aprendizagem Industrial, Chapecó, 1992.

BRASIL. Instrução Normativa ${ }^{\circ}$ 62, de 26 de agosto de 2003. Métodos analíticos oficiais para análises microbiológicas para controle de produtos de origem animal e água. Diário Oficial da República Federativa do Brasil, Brasília, DF, 18 set. 2006.

COULTER, P. Considerações importantes durante o processamento de carcaças suínas - Parte 2. Revista Nacional da Carne, 2008. Disponível em: <http://www.suino.com.br>. Acesso em: 10 abr. 2010 .
DREHMER, A. M. F. Quebra de peso das carcaças e estudo da vida de prateleira da carne suína. 2005. 131 f. Dissertação (Mestre em Ciência e Tecnologia dos Alimentos)-Universidade Federal de Santa Maria, Santa Maria, 2005.

GOMIDE, L. A. M.; RAMOS, E. M.; FONTES, P. R. Tecnologia de abate e tipificação de carcaças. Viçosa: Editora UFV, 2006. 370 p.

GUAHYBA, A. S. Tecnologia de carnes e derivados. São Paulo: Colégio Martin Lhuther, 2003.

GREER, G. C.; JONES, S. D. M. Quality and bacteriological consequences of beef carcass spray-chilling: Effects of spray duration and boxed beef storage temperature. Meat Science, v. 45, n. 1, p. 61-73, 1997. http://dx.doi.org/10.1016/S0309-1740(96)00073-3

JOAQUIM, C. F. Efeitos da distância de transporte em parâmetros post-mortem de carcaças bovinas. 2002. Dissertação (Mestre em Medicina Veterinária)-Faculdade de Medicina Veterinária e Zootecnia, Universidade Estadual Paulista, Botucatu, 2002.

LAWRIE, R. A. Ciência da carne. 6. ed. Porto Alegre: Artmed, 2005.

MACCARI, S. Acompanhamento de processos e análises dos produtos elaborados pelo Frigorífico Chapecó. 1989. 90 f. Relatório de estágio (Graduação em Farmácia e Bioquímica - Habilitação em Tecnologia de Alimentos)-Universidade Federal de Santa Catarina, Florianópolis, 1989.

OLIVEIRA, E. R. Relatório do estágio curricular supervisionado na Cooperativa Central Oeste Catarinense (Aurora). 2008. $60 \mathrm{f}$. Relatório de estágio (Graduação em Medicina Veterinária)Faculdade de Agronomia e Medicina Veterinária, Universidade de Passo Fundo, Passo Fundo, 2008.

ROÇA, R. O. Propriedades da carne. Botucatu: Laboratório de Tecnologia dos Produtos de Origem Animal, Fazenda Experimental Lageado, 2009.

SIMON, A. N. Relatório de estágio supervisionado. 1983. 100 f. Relatório de estágio (Graduação em Ciência e Tecnologia em Alimentos)-Universidade Federal de Santa Catarina, Florianópolis, 1983.

WAL, P. G; ENGEL, B; BEEK, G. A refrigeração das carcaças de suínos: efeitos da temperatura, perda de peso e qualidade da carne final. Zeist: Instituto DLO e de Ciências da Saúde Animal (DLOID), 2000.

ZANOELO, E. F. et al. Avaliação da qualidade de carcaças suínas no período de resfriamento. Revista Higiene Alimentar, v. 20, n. 143, p. 106-111, 2006. 